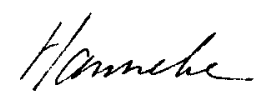

INTERNATIONAL HUMANITARIAN ENQUIRY COMMISSION

REPORT ON THE DISPLACED PERSONS IN AFGHANISTAN GENEVA - 26.04.85 


\section{TABLE OF CONTENTS}

\section{Introduction}

p. 1

Part I

- Background

- Legal aspects of humanitarian relief

- Method of work

p. 2

p. 4

p. 8

Part II

- Exodus to Pakistan

- Internal displaced persons

- Reasons for internal displacements

P. 9

- Features of the internal exodus

p. 10

- Resulting situations and needs

Part III : Action

p. 17

- Political action

- Humanitarian action

- Intervention as a duty

- Urgent and Medium-term assistance
- The right to protection

Conclusions and Recommandations

p. 27

\section{Map}

\section{Annexes}

1). Fourth Geneva Convention, article 23 Protocol I additional to the Geneva Convention, articles 70 and 71

Protocol II additional to the Geneva Convention, articles 14 and 18.

2). NGOs list

3). Article by A. Guillo, J.J. Puig and O. Roy in "Ethnologica Helvetica" $n^{\circ} 7,1983$. Only in french.

4). File concerning economic war, in "Défis afghans" $n^{\circ} 2,1985$. only in french.

5). Other sources

6). Project of the Charter for the Protection of Medical Missions. 


\section{COMMISSION MEMBERS}

Theo VAN BOVEN,

GUY AURENCHE,

Michael BARRY,

Maurice BARTH,

Richard BAUMLIN,

Mario BETTATI,

Peers CARTER,

Louis DUPREE,

Richard FALK,

René GARRIGUE,

Sexteen HEPPLING,

INTERNATIONAL FEDERATION

Edmond JOUVE,

Bernard KOUCHNER,

Léo MATARASSO,

Roelof MUNNEKE,

PAX CHRISTI INTERNATIONAL (Belgium)

Adolfo PEREZ ESQUIVEL,

Laurent SCHWARTZ,

Gianni TOGNONI,

Jacques TOUATI,

Michel VERRON,

George WALD, States)
Professor of International Law, former Director of the United Nations Human Rights Division, and President of the Commission (Netherlands).

Lawyer, International Movement of Catholic Lawyers (France)

Islamic scholar and anthropologist, observer for the International Federation for Human Rights (United States)

Protestant Minister (France)

Professor of Constitutional Law (Switzerland)

Professor of International Law (France)

Former British Ambassador to Afghanistan (United Kingdom)

Professor of Anthropology (United States)

Professor of International Law (United

Doctor of medecine (France)

Swedish Afghanistan Committee (Sweden)

FOR HUMAN RIGHTS (based in Paris, France)

Professor of International Relations (France)

Doctor of Medecine, President of Médecins du Monde (France)

Lawyer (France)

Anthropologist (Netherlands)

Nobel Peace Prize (Argentina)

Mathematician (France)

Doctor of Medecine (France)

Doctor of Medecine (France)

Former UNESCO official in Kabul, Afghanistan (France)

Nobel Prize for Medecine (United States) 


\section{INTRODUCTION}

The International Symposium on the problem of the Afghan refugees which was organized by the Bureau International Afghanistan at the University of Geneva from 4 to 6 November 1983, with the sponsorship of Pieter Dankert, President of the European Parliament, Régis Debray, author, Bruno Kreisky, former Federal Chancellor of Austria, Edgard Pisani, Commissioner for Development of the EEC, Théo C. van Boven, former Director of the Human Rights Division of the United Nations, and Simone Veil, former President of the European Parliament, decided at the conclusion of its work upon the creation of an International Commission of Humanitarian Enquiry with the task of :

\section{gathering all information concerning}

- displacements of populations and their effects upon the health, economic, social, cultural, psychological, legal and other conditions of displaced persons in Afghanistan;

- assessment of the needs of these populations as regards humanitarian aid which may be given to them by the international community and especially the international non-governmental organizations.

drawing up a report on these observations and publishing its conclusions.

This International Commission of Humanitarian Enquiry was formed in the first months of 1984. A list of its members forms the first page of the present document.

The Commission has held four meetings in Paris $(8$ October 1984, 14 December 1984, 9/10 February 1985 and 13 April 1985) in the course of which it decided its method of work, examined witnesses and experts, analysed documents, and discussed and adopted the present Report.

Research was financed by the European Human Rights Foundation (United Kingdom). 


\section{BACKGROUND}

1. Afghanistan slightly larger than France, is three-quarters mountain and desert, with only $13 \%$ cultivable land, $10 \%$ pasture and very little surviving forest. Rainfall is light, occurring between early December and March or April and varying considerably between regions; in the mountains, precipitation is in the form of snow. Altitude varies from approximatively 1000 to 7000 metres; Kabul lies at about 1800 and is in roughly the same latitude as Algiers. Much agricultural production, which is the basis of the economy and upon which the overwhelming majority of the population rely for their livelihood, depends on snow-fed irrigation and is thus critically vulnerable both to poor snowfall (as in 1970-71) and to destruction of the ancient and delicate system of irrigation channels.

2. Until 1978 Afghanistan was a strictly non-aligned Moslem country, governed by a Westernized Pashtun ruling class led by the Durrani royal family in direct descent from Ahmed Shah, who founded the kingdom in 1747. There are no reliable population figures. There has never been a census (the first population survey, with UN help, was abandoned in 1979 because of the civil warl but the best estimates suggest about 14 million people before the massive changes caused by the soviet invasion. Since Afghanistan is at the crossroads of Asia, with successive waves of immigration over the centuries (most recently, refugees from the Sovietization of Central Asial as well as many minor and occasional major invasions (Alexander the Great and Genghiz Khan passed this way, before the Red Army) the population is remarkably varied. The largest ethnic group are the Pashtuns (the original "Afghans", but the word has been expended to include all citizens of modern Afghanistan). Other major ethnic groups are the Tajiks, the Hazaras, the Aimaq and the Uzbeks, and there are many other ethnic groups, some of them very small.

3. There are over 20 distinct languages, but Dari (similar to Persian) can be used as a lingua franca except in villages in the main pashtun regions in the south and south-west where Pashto is spoken. All Afghans have a strong devotion to Islam and most are sunni Moslems, the main exception being the Hazaras who follow the shia doctrine. All have a deep feeling for personal liberty and independence even from their own central governments, let alone foreign interference. From 1747, for exactly 200 years, they were able to preserve this independence because of the rivalry between Tsarist and British imperialisms. In order to prevent the country from being drawn into the Russian sphere of influence and thus threatening British rule in India, the British invaded Afghanistan in 1838 -an invasion which ended in the retreat 
and extermination of British forces in 1842- and in 1878-1880, when the British obtained a veto on Afghan foreign policy; but at no time was the internal independence of Afghanistan compromised, and when the Amir Amanullah sued for peace after the short war which he launched in 1919, this veto was lifted, and Afghanistan became again fully independent.

4. But in 1947, when India became independent and the new state of Pakistan was born, the British strategic counterweight disappeared, the United States failed -and indeed refused- to replace it, and events were set in train which led to the soviet invasion.

5. King Amanullah, inspired mainly by the example of Kemal Ataturk in Turkey, embarked on an ambitious and in many ways admirable programme of liberalization and reform, but the intensely conservative tribesmen rose in revolt and in 1929 he was deposed and driven into exile. After a very short interlude of rule by the Tajik rebel Habibullah, called Bacha-e Saqao ("the Son of the water-carrier") Durrani rule returned.

6. Under King Zaher Shah (1933-1973) a new constitution was introduced providing for elections and a two-chamber Parliament, but the king never issued the royal decree which would have legalized political parties. There was therefore no outlet for the rising educated class, a situation which favoured the growth of underground and mainly communist political movements.

7. The British in 1893 had forced the Afghans to accept as part of their Southern frontier the Durand line, which arbitrarily cut through Pashtun tribal territory, and from 1947 onwards there was constant Afghan pressure to recover from Pakistan the lost territory, called by the Afghans "Pashtunistan". Pakistan had the support of the United States, which in 1954-55 refused Afghan requests to reequip the Afghan armed forces; the Afghans then turned to the Soviet Government which agreed to provide both the equipment and the trainina that went with it; and the USSR also gave diplomatic support to Afghanistan in the Pashtunistan issue, about which Prince Daud, the King's first cousin and Prime Minister from 1953 until 1963, felt particularly strongly.

8. The pressure engendered by the political immobilism of the régime came to a head in 1973, when the King was deposed in a bloodless Coup d'Etat engineered by officers trained in the Soviet Union, and replaced by Daud as President of the Republic, who named a Cabinet including, in addition to the officers concerned, a number of members of the Communist Party or rather parties; there had been a split in 1968 between the Khalq ("People") and Parcham ("Flag") wings. 
9. Opinions differ as to whether the Soviet Embassy was involved in the 1973 Coup d'Etat; be that as it may, Daud, evidently fearing an undue increase in Soviet influence; gradually shed his Communist Ministers and advisers.

10. Fearing also a threat from another sector of opinion, he also drove into exile in Peshawar the leaders of Islamic political groups. There was a reconciliation between Khalq and Parcham, to form the PDPA (People's Democratic Party of Afghanistan) in 1977, and in 1978 they seized power in a bloody military coup d'Etat led by the same officers who had organized the 1973 Coup. Daud was murdered, together with his entire family including small children.

11. The new regime issued a list of "reforms" many of which, like those of King Amanullah, looked desirable enough on paper but which, especially since they were propagated by urbanized Party activists without understanding of the countryside -were even more bitterly resented, and armed resistance soon declared itself. Prominent political leaders of the constitutionalist period were at once arrested and executed, and there was a campaign of terror against real and potential opposition : official lists were posted up of 17000 executions in the Pule Charki prison alone.

12. The first President of the "Democratic Republic of Afghanistan", Nur Mohammad Taraki, was overthrown (and killed) in August 1979, and replaced by his Deputy Prime Minister, Hafizullah Amin, under whom the reign of terror was intensified. But this did not stop armed resistance in the countryside, which on the contrary spread and was accompanied by mutinies in the Army. It was clearly only a matter of time, and a short time, before the régime would be forcibly overthrown; and on 27 December, 1979, a massive Soviet invasion swept into Afghanistan, killed Amin and installed the present regime under President Babrak Karmal.

\section{LEGAL ASPECTS OF HUMANITARIAN RELIEF TO CIVILIAN POPULATION IN AFGHANISTAN}

13. Three categories of persons belonging to the Afghan civilian population can be distinguished. First, civilians living in territories under the control of the Kabul authorities. Second, civilians living within the borders of Afghanistan in territories not under the control of the Kabul authorities. Third, civilians who have fled from Afghan territory and who live as refugees in neighbouring countries, in particular in Pakistan and in Iran. The welfare of the first category of persons is the primary responsibility of the kabul authorities. The welfare of the third category of persons is dependent on the joint efforts of the governments of the countries where these persons have found refuge and the inter-governmental and non-governmental organizations in charge of the protection and relief to refugees. However, 
with regard to the second category of persons they are largely deprived of any national and international assistance. As human beings they are equally entitled, on the basis of elementary human rights and humanitarian standards, to a life and existence which corresponds to the dignity and worth envisaged in the Universal Declaration of Human Rights.

14. It is this special category of civilians who are deprived of any official protection and assistance that is the primary concern of the humanitarian commission of enquiry. As a matter of fact, assistance and relief activities of the United Nations and their related agencies are barred from reaching these civilians, because all these agencies operate within the official inter-governmental framework of which the Kabul authorities form a part.

The latter have consistently refused permission for any assistance and relief coming from the inter-governmental community to be channelled to non-combatants in Afghan territory who are not under the control of the Kabul authorities. They have also refused to allow the International Red Cross to carry out protection and relief activities in the country.

15. In making an appeal for help for this deprived category of people in Afghanistan, the humanitarian commission of enquiry takes into account that certain humanitarian non-governmental agencies have been acting as substitutes where the inter-governmental community is prevented from securing for these deprived people the basic rights and facilities they are entitled to. In this respect these humanitarian nongovernmental agencies are carrying out a high moral duty which has its basis in the laws and obligations of human kind. It is therefore of great importance that some of the relevant premises of human rights and humanitarian law be reviewed.

16. It cannot be contested that all peoples and all human persons, whatever the status of the territory on which they live, are entitled as a priority and primary matter to the right to life and to survival. This is a basic premise of the whole body of human rights and humanitarian law and holds its validity irrespective of whether or not the governments concerned have ratified international instruments in the field of human rights and humanitarian law.

In this respect it should be recalled that in international law there is a growing recognition of obligations which by their very nature are so fundamental that the international community as a whole has a legal interest in their protection. These obligations are the concern of all states and oan be consiuered as obligations erga omnes. As the International Court of Justice stated (Case concerning the Barcelona Traction, ICJ Reports 1970, p.32) : 
"Such obligations derive, for example, in contemporary international law, from the outlawing of acts of agression, and of genocide, as also from the principles and rules concerning the basic rights of the human person, including protection from slavery and racial discrimination".

The humanitarian commission of enquiry has no doubt that the right to life and survival falls as a basic right of the human person and of peoples within the category of rights which correspond to erga

Moreover the humanitarian commission wishes also to refer to the general comments of the Human Rights Committee which in its interpretation of Article 6 of the International Covenant on Civil and Political Rights (Report of the Human Rights Committee to the thirty-seventh session of the General Assembly, UN doc. A/37/40, Annex V, \$ 1-7) has pointed out that the right to life cannot properly be understood in a restrictive manner and that the protection of this right requires the adoption of positive measures. Among such measures are actions of an economic, social and humanitarian character. The commission of enquiry deems that humanitarian relief activities in order to spare peoples in acute danger and to save the lives of human beings in great distress are not only a moral duty but also a prescription of international law. Without the acceptance of this basic premise the Universal Declaration of Human Rights, which is generally considered as having become a part of international customary law, would lose its value as a universal standard.

This implies that whenever and wherever peoples and persons are being threatened in their very life and survival, they are legally entitled to protection, assistance and relief, also in cases and situation where matters of jurisdiction and sovereignty are in dispute or where an international or non-international armed conflict has given rise to a state of exception. The some basic premise also implies that organizations and groups whose sole aim is to provide humanitarian protection, assistance and relief should have full and unimpeded access to these peoples and persons in distress. Any measures taken against such organizations and groups carrying out essential human rights and humanitarian duties would be in contradiction with basic principles and laws of humankind.

17. In the above considerations we have relied on elementary principles and notions of human rights and humanitarian law which we hold applicable with regard to peoples and persons who are of special concern to the humanitarian commission of enquiry and to the other humanitarian nongovernmental organizations that provide assistance and relief to noncombatants living in great distress in Afghanistan but not under the control of the Kabul authorities. In addition we may have regard to conventional provisions of humanitarian law which are applicable to the situation in Afghanistan. 
The principal question to be determined is whether the present situation in Afghanistan can be considered as of an international armed conflict and is as such governed by the Geneva Conventions of 12 August 1949 and by Protocol I additional to the Geneva Conventions and relating to the protection of victims of international armed conflicts. With regard to this question the humanitarian commission of enquiry endorses the views expressed by the Permanent peoples Tribunal at its two sessions on the case of Afghanistan, held in stockholm, 13 May 1981, and in Paris, 16-20 December 1982 (texts included in "Un tribunal pour les peuples", sous la direction d'Edmond Jouve, Paris, 1983, p. 168-226). In accordance with the views of the Permanent Peoples Tribunal, it is submitted that the situation in Afghanistan is covered by the wording of artticle $I, \$ 4$, of the above-mentioned Protocol I which includes under its scope of application :

"... armed conflicts in which peoples are fighting against colonial domination and alien occupation and against racist régimes in the exercise of their right of self-determination, as enshrined in the Charter of the United Nations and the Declaration on Principles of International Law concerning Friendly Relations and Cooperation among States in accordance with the Charter of the United Nations".

The struggle of the Afhgan people against the acts of aggression by the Soviet Union and against the continued occupation of Afghan territory by soviet troops with the collusion of the Kabul régime is a fight against alien domination and occupation in the exercise of the right of self-determination of the Afghan people. Consequently, Article 23 of the Fourth Geneva Convention and Articles 70 and 71 of Protocol I additional to the Geneva Conventions (the texts of these articles are reproduced in Annex I of this report) concerning relief actions in favour of the civilian population and the protection of personnel participating in relief actions should be repected. The humanitarian commission of enquiry wishes to stress that the relief actions are to be humanitarian and impartial in character and that rapid and unimpeded passage of such relief assistance should be ensured. For more detailed perscription in this regard reference is made to the relevent just mentioned provisions of the protocol. The overriding aim of these provisions is that the civilian population in the armed conflict should not be deprived of their basic needs and should be furnished wiht all supplies essential to the right to life and survival.

18. But even if one holds the view that the situation in Afghanistan would not be covered by Protocol I additional to the Geneva Conventions and amounts only to what falls under the scope of Protocol II, the attention should be drawn, as a subsidiary legal basis, to the survival provisions as contained in articles 14 and 18 of the latter Protocol 
(the texts of these articles are also reproduced in Annex I of the present report). The humanitarian commission strongly believes that in the light of the imperative nature of survival norms, all authorities are duty bound to lend their cooperation in order to facilitate humanitarian relief activities undertaken to spare peoples in acute danger and to save the lives of human beings in great distress.

\section{METHOD OF FORK}

19. As emphasized above, the Commission's attention centred on displaced persons in regions not under the control of the Kabul authorities. However, in order to undertake as exact a description as possible of these situations and in order to understand their workings, it was necessary to consider the phenomenon of displacements as a whole, whatever the status or situation of the areas which the displaced persons eventually reach.

20. This report does not claim to present a statistical picture nor a sociological study of displaced populations in Afghanistan, even those in the "liberated areas" alone. Such a study is impossible in present circumstances : there are no qualified research personnel in the field, the phenomenon is inherently unstable, and the situations vary enormously not only because of the physical, geographical and ethnic heterogeneousness of the country but also because of the variety of the politico-military dispositions used by the Soviet-Afghan forces; not to mention the major difficult $y$ of obtaining at least the neutrality, if not the co-operation, of the Kabul authorities in such an undertaking.

21. In any case, no such study is necessary to show, with evidence, that this drama exists and affects tens of thousands of Afghan families. In the course of its meetings on 8 October and 14 December 1984, and 9 and 10 February 1985 in Paris the Commission has been able to hear the direct evidence of a number of people returning from Afghanistan. The commission then judged that by referring to further witnesses, it could obtain a body of evidence solid enough to enable it to draw up its report.

22. The Commission therefore entrusted certain of its members with the task of gathering as much available information as possible, with the technical help of the BIA.

23. The Commission's information came from sources of two kinds, direct and indirect, the latter consisting mainly of reports by organizations, final acts of symposia or specialized studies. From direct witnesses the Commission received a great many pieces of evidence about the situation of displaced persons in Afghanistan. Some of these 
people sent written evidence to the Commission and others were interviewed by the BIA; further information has been extracted from reports, articles or publications written by direct observers at the end of their time in Afghanistan. A certain number of such documents are annexed to this report.

24. Most of the evidence comes from doctors and nurses who have carried out medical missions inside the country since 1980. Some of it also comes from journalists and specialists who go to Afghanistan regularly and from Afghans who have become refugees in Pakistan or who live in Afghanistan and regularly visit Pakistan.

25. Cross-checking this abundant evidence, the Commission is able to give a sufficiently accurate description of the phenomenon of displacement of populations. But it is first necessary to distinguish between several kinds of displacement.

26. Because it is on such a massive scale, the phenomenon has been observable by everyone who has been into Afghanistan in recent years, even though the study of these displacements was not their main concern.

There are individual movements, but these are exclusively by men : young people leaving the towns to avoid conscription into the army or the militia, deserters, or peasants from frontier areas who have taken refuge with their families in Pakistan but who go back at certain seasons to cultivate their land or gather the harvest.

Without overlooking this aspect, which is also connected with the war, the Commission has essentially given its attention to displacement affecting whole families.

\section{PART II}

\section{EXODUS TO PAKISTAN}

27. Movement of populations began in the second half of 1978 and reached a rate of tens of thousands of persons a month as from January, 1980, immediatly after the Soviet intervention, as witnessed by the statistics of the UNHCR in Pakistan. These movements essentially affected the Pashtun populations of the eastern, south-eastern and southern frontier regions until 1983. From 1984 they have also affected the Tajik, Uzbek and Turcoman peoples of the northern provinces. They are still continuing and bear witness to the intensification of the war and the deterioration of the living conditions of the people. 
28. These caravans of families with their women, children and old people, and sometimes a few livestock, are undertaking a journey which will last almost two months before they reach the refugee camps in Pakistan. The exhausting conditions of the journey are aggravated by the difficulties of movement in the devastated regions through which the caravans must go, by crossing snowbound passes, by illness and above all by the horror of air attack. During the sumer of 1984, journalists and doctors in the mountains of the north-east near the Pakistan frontier met caravans of refugees who had been bombed and machine-gunned. The Commission emphasizes the total absence of any protection for these civilian populations between their starting points and the Pakistan frontier.

\section{INTERNAL DISPLACED PERSONS}

29. The refugee populations in Pakistan and Iran form the largest concentration of refugees in the world. The statistics issued by the Pakistan and Iranian Governments and by the UNHCR indicate a cotal number of about 4 million. It is more difficult to estimate the number of displaced persons inside Afghanistan, also called "internal refugees". The specific information obtained by the Commission does however enable it to state with confidence that this is a large-scale, long-lasting phenomenon which affects the country as a whole and affects between 1,5 and 2 million people.

30. From Spring, 1980, after the first Soviet offensive against the Panjshir valley, several thousand Panjshiri families sought refuge in Kabul. This was the first large-scale influx of refugees into the capital and was recorded by a number of European witnesses who were at the time working in Kabul.

Since that time, the problem of accomodation in the capital has become critical, with several refugee families squeezing into the houses of friends. The population of Kabul has more than doubled in five years and is approaching 2 million inhabitants $(750,000$ in 1978).

The refugee families come from the villages of the shamali and from provinces surrounding the capital, for example Kapisa, Istalif, Paghman, Deh Sabz, Bagrami, Logar, Maidan and Ghorband.

31. The phenomenon is not limited to Kabul, but it does not affect all other towns in the same way. Mazar-i-Sharif in the north, Jalalabad in the east, Ghazni and Gardez in the south-east centre also receive refugee populations from the surrounding villages, but the two largest cities after Kabul, Kandahar in the south and Herat in the east, have on the contrary seen part of their populations flee, either abroad (the Kandaharis to Pakistan, the Heratis to Iran) or to the nearest mountain foothills. 
32. 1,5 million is a reasonable estimate of the number of country people who have sought refuge in the towns, thus considerably accentuating the classical phenomenon of rural exodus. Before the war, one Afghan in 8 lived in a town; in 1985 the proportion is 1 in 3.

33. Observers have recorded mass movements, which have increased in 1984, among rural populations who have neither taken refuge abroad nor in the towns and whose number can be estimated at 7 million. We quote below a certain number of cases which illustrate the scale and the generalized nature of the phenomenon.

\section{All regions of Afghanistan are affected.}

In the north-east, more than 2500 families from the Panjshir have been counted in the region of Khost-e-Fering and Nahrin.

In the north (Takhar) hundreds of families have evacuated the villages of the Shulgar valley and of Sangcharak. Half of these families have fled towards Pakistan, and the other half to villages further south, in the mountains.

The same thing has happened in the plain of Chakcharan in the west-centre : villages have been abandoned and their populations have sought refuge further up in the hills.

The same kind of exodus has occurred in the Maimana region and in the whole province of Faryab in the north-west, with the same retreat from the villages towards the hills where families construct small makeshift houses.

In the west-south-west, in the region of Farah, the exodus is reported of 2000 Baluch families to the southern borders of Nimroz province.

To the west of Kabul, in the province of Wardak, doctors report the presence of 400 refugee families from the Hazaradjat and of several thousand people from the neighbourhood of Ghazni.

In the south, in the region of Kandahar, more than half the villages within a $20-k i l o m e t r e$ radius of the provincial capital are deserted, $2 / 3$ of their population having sought refuge in pakistan and $1 / 3$ in the mountains to the north of the province, in the southern foothills of the Hazaradjat.

All the evidence agrees that to the east, in the provinces of Logar, Paktia, Nangarhar and Kunar, the villages in the plains are practically deserted. A Dutch journalist who has visited this part of the country several times, particularly Logar, asserts that half the population (estimated in 1975 at 314,000 ) have gone, and that certain areas are $100 \%$ deserted. Most of the families who have fled have found refuge in pakistan. In these frontier regions, internal 
refugees are few, except for the minority who have gone to the towns : Gardez, Ghazni and Jalalabad. On the other hand, all these provinces are transit areas for caravans of refugees on their way to the camps in Pakistan.

34. Afghan rural society is traditionally stable. Before 1978 the rural exodus was, even relatively, smaller than in other countries at the same stage of development. Kabul remained a capital with a relatively modest population. $(750,000)$. The populations of the other large towns, Herat and Kandahar, hardly exceeded 100,000.

35. 608 of the population lived on 25 of the surface of the country. This more heavily populated area (population density 30 to 60 per square kilometrel lies roughly to the east of a diagonal line passing through Mazar-i-Sharif and Ghazni (but excluding the province of Badakhshan, a region of high mountains with a population density of less than 10 per square kilometrel. The great majority of the refugees in Pakistan have come from these provinces.

From the west of this line, except for the provinces of zabul and Kandahar whose refugees generally reach the camps in Pakistan, most of the refugees have gone to Iran.

There is one exception : the Hazaras, who like the Iranians follow the Shi'a doctrine, have since 1984 emigrated towards Peshawar and no longer towards Iran or Quetta as formerly.

36. The only population movements before the war were those of the nomads. Long-distance nomadism, which affected nearly a million people (Kuchi) has been completely upset by the war (cf. the article in Ethnologica Helvetica $n^{0} 7$ of 1983 by A. Guillo, J.J. Puig and O. Roy) and partly destroyed.

In the south of the country, in Kandahar province, a development has been observed whereby nomads become sedentary; there is even talk of "shanty-towns nomads" in areas under Government control, but this has not been directly observed.

\section{REASONS FOR INTERNAL DISPLACEMENTS}

37. In the rural and stable society of Afghanistan, these huge shifts of population have of course been caused by an exceptional situation : the events following the military coup d'Etat of April 1978, which have developed and spread significantly since soviet troops entered the country at the end of 1979 .

The basic, and only, cause is the war.

38. On the basis of evidence received from many witnesses, the Commission has thought it right to define the particular conditions which 
have brought about the exodus of populations. The events which caused them to flee differ from time to time and from place to place, as does the manner of movement.

39. The most obvious immediate cause is the bombing of villages, with the destruction of houses, harvests and sometimes livestock, not to speak of civilian casualties. After burying the dead, the families flee. Even if flight after the first bombardment is not a mass movement, it becomes one as the cycle of terror gathers force.

The evacuation of villages can occur before bombardment. Such was the case in the Panjshir during the most recent offensives against the valley.

Outside the Panjshir, and considering only internal as distinct from external refugees, a certain number of observations from almost all parts of Afghanistan are mentioned in paragraph 33 above.

After studying these cases, and bearing in mind that the regions most affected by the war are strategically significant (towns, lines of communication, military bases, industrial areas) and that they form an almost complete belt round the central mountains of the Hazaradjat, the Commission notes that the phenomenon of displaced persons affects all the regions in question and that these internal movements are always towards the mountains nearest to the areas abandoned, except for the regions in the south-east whose populations seek refuge in Pakistan, and those in the south-west whose populations seek refuqe in Iran. (see the map at the end of the present report).

40. Fighting or military operations on land, which cause prolonged insecurity in certain regions, also lead to the evacuation of villages as in the Logar, in the neighbourhood of the large towns, in the Kunar and in the northern regions.

41. A further cause of displacements is civil war between opposing resistance groups. This has happened mainly in the Hazaradjat where the traditional resistance movement (Shura-Etefaq) has gradually lost its dominant position vis-a-vis groups inspired and assisted by the Iranian Islamic revolution. The case of 400 Hazara Shi'a families found in the Pashtun region of Wardak is mentioned above.

42. Collective fear, which often amounts to panic, causes the flight of village people. Fear of reprisals following a Resistance operation (such reprisals have become a normal event in Afghanistan); house to-house searches, checking operations, press-gangs looking for young conscripts; also in some cases punitive operations conducted by some Resistance group against villageds which have been "pacified" 
or have passed under the control of an antagonistic Resistance group (this last kind of operation has become more and more infrequent but was widespread in certain regions, for example Logar and Shamali, in the first years of the warl.

43. The "Ethnologica Helvetica" study mentioned above (\$36) refers to another cause of population exodus. The authors call it the "Hejrat
protest exodus", and write :

\begin{abstract}
"Following the example of Muhammad leaving Mecca for Medina, many Moslems consider it a religious duty to leave what was ceased to be a land of Islam for another Moslem country. Such a hejrat (1) protest exodus is always collective, organized and inspired by traditional notables, khan or mullah ; it implies the movement of a structured group to a foreign country, usually Pakistan, where it retains its cohesion for a certain length of time. We can quote for example the Kirghiz of the Pamirs under Rahman Qol, the Baluch of the Helmand under their leaders Sanjarani and Gurgich, the Sabari tribe of Paktia and the inhabitants of the Kunar valley. If the deciding factor is not the seriousness of the military or economic question, a particular threat can start the movement. such an exodus of protest is almost always that of a tribe. However, a curious case of hejrat within Afghanistan is that of the Cheshtiya Sufi brotherhood of Chest-i-Sharif in the province of Herat : in consequence of a sermon by the ulemas of the brotherhood which referred explicitly to the Medina hejrat, 300 of the 400 families left their homes on a single day, 11 April 1981, to take refuge in the surrounding mountains where they are carrying on the war under the leadership of the murshid, the spiritual guides of the brotherhood".
\end{abstract}

44. Any one of the above factors can occur in isolation, but usually the decision to move results from the cumulative effect of several. However, in addition to those already mentioned there is another of which Western opinion has only recently become aware, though it has certainly been present for a long time : hunger and poverty.

When, in months of war, a community has seen its harvests destroyed and its livestock decimated, the surrounding bazars closed or desperately lacking in basic foods, when money has run out; even if their houses are still standing, what can a family do to survive except flee to some area where they will be received as friends and

(1) the words hejrat and mohajer, refugee, have the same semantic
root. 
where they can be sure of tomorrow's bread for their children? The danger of famine as a cause of exodus has been illustrated by many observations and reports, especially by the research document by Dr. Francès d'Souza, the symposium organized by the BIA in Paris in November 1984 on "Food in a war Economy : Afghanistan", and the Press conference of 12 December arranged by the French medical organizations and by European Humanitarian Co-ordination (see annexes 4 and 5).

\section{FEATURES OF THE INTERNAL EXODUS}

45. The factors leading to population exodus mentioned above apply to all displacements of population, both to those which swell the rural exodus to the towns and to those which end in the refugee camps. They also apply, of course, to people seeking refuge in other rural areas in Afghanistan. But why do these people refuse the asylum offered by the refugee camps or the capital ?

We are concerned here with a complex attitude in which cultural, sociological and political factors interlock. Professor Majruh, former Dean of the Faculty of Letters at Kabul University and now Director of the Afghan Information Centre in Peshawar (cf. his article in "Défis afghans" $n^{\circ} 2$ ) has defined the three dimensions of the individual identity of the Afghan countryman : his land, his wife and his tribe. When he can no longer remain and work in safety on his land, he leaves it with his wife and his family, but he will do everything possible to stay within his clan and within his tribe.

46. Thus the Pashtun populations which have a strong tribal structure have taken refuge more rapidly and in greater numbers than other ethnic groups in Pakistan, and have been able there to reconstruct the tribal fabric.

The other ethnic groups, especially the Tajiks but also the Uzbeks and the Turcomans, usually try not to go too far away from their land and their homes, hoping that they will soon be able to return.

The Commission has mentioned above the people of the plains who seek provisional refuge in the hills. These people feel the need in some way to remain "physically" in touch with their land.

47. This is why internal displacements of populations in rural areas are in every case displacements over relatively small distances not exceeding 100 kilometres.

48. In addition to his attachment to his land and his will not to leave it, the Afghan countryman feels the sense of belonging to his 
family, to his tribe, to his clan and to his ethnic group : this is his real fatherland. Beyond it, until quite recently, everything was foreign if not hostile. This was especially true of the three largest ethnic groups, Pashtuns, Tajiks and Hazaras. It is easy to understand the reluctance, even the fear, of rajiks from the north or Hazaras from the centre in crossing the Pashtun regions of the south and southeast, as they must in order to reach the refugee camps in Pakistan.

49. These two factors, attachment to the land and having a common language, culture and tradition account for the fact that the phenomenon of internal displaced families is one which affects the non-Pashtun areas. In Pashtun areas, these same factors have led to the exile en masse of populations to Pakistan and into camps located in areas of similar culture and ethnic group, where the refugee populations have pretty well rebuilt their tribal structures.

50. There may also in some cases be political factors. In regions such as the Panjshir where the armed resistance lives in osmosis with the non-combatant population and where commanders concern themselves with the organization of this population and the management of community affairs, these military leaders have in the course of the war years won the confidence of the non-combatant populations among whom they enjoy great authority. In such situations, the leaders decide on the evacuation of villages and the destination of the evacuees. Thus in November 1984, on the thresholdof winter, Commander Massud advised thousands of Panjshiri refugee families in the mountains to go either to Kabul or even to Pakistan to wait for their return to the valley when that became possible.

51. Finally, there are sometimes other reasons which prevent families from taking the road to the refugee camps : lack of money or of means of transport, absence of a husband or father to take responsibility for them on the way. Such families seek refuge in nearby villages where they may find a welcome with friends or relatives, and in areas less affected by the war.

Thus, as one witness has observed, these families of internal refugees are sometimes hidden from the local people thanks to local leaders who may arrange for them to be received secretly, and with whom they have old links. Secretly, in order to avoid reprisals, keep the district out of trouble and maintain good relations with Kabul.

Some observers believe that the presence of these "foreign bodies" grafted on to "clean" populations may on the one hand cause disturbances and on the other make it unlikely that the receiving population will stay out of trouble much longer. They also believe that this first displacement is the beginning of a displacement which will inevitably lead these families in the end to exile in Iran or Pakistan. 


\section{RESULTING SITUATIONS AND NEEDS}

52. The needs of the displaced people are similar to, and blend with, those of the receiving populations. The arrival, often en masse, of dozens or even of hundreds of people in a village, a town or a neighbouring valley has immediate economiceffects : prices rise, reserves (of food, fuel, etc.) are reducea, problems of accommodation and availability of basic necessities are accentuated.

The problems of community life which result from an influx of displaced persons are even more serious :

a) problems connected with the presence of differing ethnic groups, but these are rather uncommon because ethnic groups tend to re-group among themselves ;

b) problems arising from the fear that the displaced people may bring with them an aggravation of military action.

According to many witnesses, the combined effect of the worsening of both the economic and the military situations is bound in the long term to lead to exodus from the country.

53. The Commission nevertheless insists that the situations of the displaced people and of those who receive them are inseparable. Bearing in mind that the main function and concern of the commission is to identify the most elementary needs of the displaced persons :

the Commission must recognize that in certain cases these needs are indistinguishable from the elementary needs of civil populations as a whole. Where there is a danger of famine, where there is no health or educational structure and the threat of war is ever-present, one can state that all these people are threatened in their way of life and in their very survival. The Commission has taken cognizance of reports which establish such a situation, and refers to paragraphs 64 to 76 for action which may be undertaken.

54. The most dramatic situation is that of displaced people who have been unable or unwilling to take refuge in villages, for example the Panjshiris in the mountains round valleys adjacent to the Panjshir, and the semi-nomads of the northern provinces who leave the war-torn plains to live all the year round in very precarious shelters in the upland summer pastures.

Although the risk of bombardment is small in the mountains, conditions of life there are very perilous. There is little cultivable land and no means of irrigation, and the climate is harsh. with the arrival of winter, the position becomes intolerable.

55. Dr Chantal Bruno-Callot of Aide Médicale Internationale spent two weeks with displaced Panjshiris in June 1984. 
"There were about a hundred of them, gathered on the mountain at an altitude of 3500 metres $(11,500$ feet). There was nothing but stones and a meagre pasture near a stream. It froze at night, and the sun was merciless by day. Most of the refugees were children. There were also many women, only a few old men. The younger men were fighting. We were with the rock-dwellers. The animals were getting thinner and thinner; so were the children.

We were to share their life for two weeks. At $40^{\prime}$ clock every morning we went to shelter among huge rocks on the mountainside. Each refugee melted into the rock, his protection from view and from the deadly fire of the helicopters and Migs which passed and passed again daily. One did not see the refugees, who had learned an extraordinary protective mimicry. At 1200 we went back to the slightly flatter place where our bedding was. We collected all the twigs we could find to make a fire; here and there thin smoke showed there women were cooking bread or rice, or making tea. The refugees offered us food, but they had so little for themselves that we refused it and bought some from an Afghan who was selling at exorbitant prices. Everything had at least doubled (rice from 40 to 90 afghanis, a very few eggs at 5 to 12 or even 15 afghanis). Everyone was constantly hungry.

Only 15 days with "the children of the stones" who, whatever their age, were amazingly silent : no tears, no laughter. They collected twigs to burn, watched their flocks, went to bring up freezing water. They learned willy-nilly what war meant : hiding, one scanty meal a day, milk or yoghourt, bread, rice, tea. They were cold, hungry, hot, frightened...

We left behind us people who had no more flour, no more tea, no more rice, nothing but livestock producing less and less milk.

15 days for us, how many days for them ? They had only one hope, to return to their valley, their own Panjshir. But their valley was not only cut off, it was ruined. The Tupolevs and their huge bombs had destroyed the houses and the future harvest, the fruit trees had been cut to ribbons, the irrigation channels mined...

What did the future hold for them ?"

56. Two years ago, 70 families moved from Badeel (Nuristan) to Merit (Kunar), after very heavy bombardments. 
An eye-witness who met them at the time gave evidence to the Commission that in December 1984 they were still there, without work and without food. They went along the Pakistan frontier where they begged or sold beasts from their flock to buy sugar and tea. The witness was struck by the fact that they had survived so long, given the very harsh winter climate.

57. Another eye-witness, a journalist who travelled in Afghanistan from May until August 1984, met many displaced people from the Panjshir valley. Throughout his journey, he saw refugees crowded into village mosques, sheltering in caves or making flimsy shelters, like tents made of bits of rag or leafy branches held up by heaps of stones. They had no longer any land or harvests, only a few goats, a few sheep,
a donkey.

Mohammed Isa, whom he met on 25 July 1984 at Djazpol (Laghman) and who had been a refugee for 5 months, had had to sell his live stock and had no money or food left; he intended to leave for Pakistan. 400 families from the Panjshir were at Gezia (Laghman), sheltered by the local people. The men and unaccompanied children were living in the mosques. The refugees settled along the roadsides, as high as there was burnable wood to be found. They were short of everything: fuel, food, warm clothes, blankets and shelter. They had no doctor and no medecines, in short, nothing, and it is not difficult to know their needs; the witness concludes :

\begin{abstract}
"One only needs to imagine oneself, with one's whole family, in a cave or under the open sky, with almost nothing left to eat, not enough clothes, shoes or blankets, no firewood left and winter coming when everything will be cold and damp, and there is nothing to do and no money. They want to go back home and hope that it will be soon; they do not want to settle permanently anywhere else".
\end{abstract}

58. According to a witness who was in the southern part of the country, around Kandahar, in september 1984, the civilian populations who have taken refuge in the mountains of the southern Hazaradjat are in danger of famine. The oases they were living in (Arghandab and Pasmul) have been completely destroyed, bombing continued daily, the relatively dry summer had reduced the 1984 harvest and it would be difficult to make it last until the spring harvest of 1985.

59. In the region of Chakhcharan in the western Hazaradjat the people, weary of bombardments and of constant raids in search of property and of men for conscription, left their homes and took refuge higher up in the hills where they built themselves new houses but could find only a little cultivable land available. The semi-nomads have settled permanently in the summer villages, and they pass the winter in tents
in the snow. 
In the Aimag country in the mountains to the north of Chakhcharan the harvest of September, 1984 was very poor for lack of enough rain; and because of the disorganization of communications trade between valleys has become difficult, as has the bartering which took place formerly and which enabled valleys in distress to find supplies elsewhere. Moreover, the peasants have no cash reserves left. For this reason, many men have left to seek work in Iran. The food situation, according to an eye-witness, was precarious in the extreme.

60. A witness who spent two months -August/September 1984- in the region of Badakhshan in the north of the country reports that the food situation in Darwaz (on the Soviet frontier) was disastrous and that it was very grave in the whole region. He observed cases of latent malnutrition among Panjshiri refugees in the valleys of parian and Khost-e-Fering. These people are only temporarily settled, in tents; their only possessions are a few sheep and goats, and they refuse to go to Pakistan. Prices have risen, and because of the interruption of communications there is a tendency to autarky in each valley.

61. Orphans or children abandoned because of the misfortunes of war are a new problem. In traditional society such children were automatically adopted by the extended family; orphans did not exist as a class. Now that the family is dispersed or has left, children left alone are abandoned. The witness who provided these data to the commission stated that it is mainly children over 8 years old who suffer trauma, those who knew peace-time conditions. They survive by begging and stealing, moving in gangs from valley to valley. Although in practical terms they are very mature, they are politically vulnerable. They do not understand, and either involuntarily or sometimes voluntarily they form an intelligence network for the khad (secret police). Military commanders and political leaders mistrust them.

The witness saw no female children; he supposes that they are hidden somewhere in houses.

The film by Christophe de Ponfilly and Bertrand Gallet "Les Combattants de l'Insolence" (1985) shows a band of these urchins passing each other cigarette-ends and then running away, good-humouredly chased by the owner of the shop in front of which they had settled.

62. Particular attention should be given to displaced people on their outward journey.

As started above, many people are now leaving the country even when they come from the regions furthest away from the Pakistan frontier and must undertake a journey of 4 to 6 weeks or even longer. These convoys of refugees, with their goods and livestock, are often bombed by the Soviet-Afghan forces. This has been observed in the interior of the Hazaradjat and of Wardak, as well as in Kunar and Laghman. 
On the other hand,refugees leaving for Iran do not undergo bombardment except in case of "misunderstandings" at night. Moreover, the distance to be covered to reach Iran is very much shorter, which makes the journey easier.

The needs which were especially mentioned to the Commission in relation to this category of persons on the move are the needs of the children. Some of them make the whole journey on foot, other are tied on to donkeys or camels. Great heat and intense cold alternate, for night in the Hindu kush is often freezing even in summer. All the refugees are badly shod and ill-equipped with bedding and warm clothes.

They are entirely without medicines or medical help. Many of these children are ill, their complaints varying from plain colds to malaria. The possibility should be examined of setting up one or two dispensaries ar the foot of passes leading to Pakistan.

There can also be cruel shortages of food on these outward journeys, as emphasized by a witness from whom refugees he met on top of a pass begged bread for their children, on 17 April 1984.

We should however emphasize that evidence agrees that the people of the transit regions are not only not hostile but are even welcoming to refugees on the move. They suffer no hostility and no brigandage, a human relationship quite different from what one has heard from Cambodia and Thailand. And this is so even in the cases, which have become frequent, of traditionally antagonistic groups who meet and get to know each other against a background of war and common distress.

All the same, it is clear that the fact of knowing thatonce in Pakistan they will receive the help they need, is for the refugees a strong comfort against the hardships of the journey. It also enables them to invest all their remaining property in provision for the journey, and to sell livestock if need be along the way.

\section{Conclusions}

1) Movements to towns, villages or other inhabited valleys : it is very difficult to give an account of the needs of displaced persons, since they overlap with those of the local populations. We may however emphasize a general tendency to rising prices and to acute shortage of basic necessities.

2) Movements into high valleys, mountains and hill country no affected by the war : ressources in such places are very limited and climatic conditions extremely harsh. Needs cover every aspect of daily life. 
3) Movements towards Pakistan or Iran : during the outward journey it is the children who are the most vulnerable and who suffer the most cruelly. The refugees are often very ill-equipped. There is no medical help.

\section{PART III}

\section{ACTION}

64. This report has emphasized several times that the tragedy affecting a whole people is the result of the war, and as long as the war goes on it will continue to sustain and extend the tragedy. The Commission appeals to the international community

a) to work unremittingly to bring this war to a conclusion which respects the rights of the Afghan people:

b) to take action without delay to relieve the sufferings of the Afghan people and especially those most deprived, without help or protection of any kind: the internal refugees.

International solidarity, if it is to be clear-sighted, realistic and effective, should neglect neither of these requirements.

\section{POLITICAL ACTION}

65. The Commission believes that the five principles upon which the Secretary-General of the United Nations Organization and his special Envoy have based their action with a view to promoting a political solution of the Afghan problem, constitute a serious base for the opening of negotiations.

However, the Commission considers that the talks which have taken place so far and which have led to no substantial progress, will not reach a conclusion until all parties concerned, including the main protagonists, take part in the negotiations. The Commission considers that any search for a solution is illusory which does not include the Afghan Resistance in the negotiations.

66. The Commission hopes that the Afghan resistance may be associated with all national and international meetings at which the problem
of Afghanistan is discussed. 
67. Given the scale of the needs, of which this report gives only an incomplete description, the Commission considers that the assistance required to attempt to meet them should no longer be undertaken only by non-governmental organizations. These deserve encouragement, but if their actions are to have any kind of significant effect, it is necessary that they should have increased financial support from states.

68. The Commission wishes to question the international organizations concerned, in the light of the specific mandate given to each of them by the international community, about their duty to help hundreds of thousands of human beings who are today living in precarious and often disastrous conditions in regions beyond the control of the Kabul authorities.

Why should children not living in urban areas or in districts not controlled by Kabul not have the right to be vaccinated, educated, fed by UNICEF, WHO and UNESCO ?

69. The Commission believes that in Afghanistan, as for that matter in other parts of the world, urgent action to preserve basic human rights and to meet basic needs cannot depend simply on the good-will of a government. For this reason the Commission earnestly by particularly requests the responsible authorities of UNICEF, WHO, FAO, WFP and UNESCO, and also the International Red Cross and the Red Crescent, programmes of assistance to displaced populations in areas beyond the control of the Kabul authorities.

In any case, the Commission believes that non-governmental organizations have an indispensable part to play in the present context of the war.

In fact, the NGOs so far present in Afghanistan have acquired direct knowledge of the country and have, year by year, established firm contacts with the Afghan people. They are thus able to know what is needed and to carry out projects of food and other humanitarian aid.

70. It is however indispensable that the NGOs which are aiding displaced populations should be assured by Governments and international agencies of the means required to carry on their work. 
71. It has already been stated, and the Commission wishes to reaffirm, that there is a duty to intervene where elementary human rights are disregarded.

The Report on the Human Rights situation in Afghanistan, drawn up by Mr. Felix Ermacora, Special Rapporteur, in application of the 1984/85 Resolution of the Human Rights Commission, records a "situation of flagrant denial of human rights". The basic norms of the Universal Declaration of Human Rights (especially Articles 3, 5, 9, 10, 11 and 18) are systematically violated, as are the provisions of the International Covenant relative to Civil and Political Rights ; the rules of international human rights are being ignored.

72. Given this statement, which only confirms what has already been denounced and condemned by the Permanent Peoples' Tribunal, Helsinki Watch, Amnesty International and others;

given that the denunciation of such violations, while it has major importance in making public opinion aware of the facts, is not enough to restore human rights :

the Commission, recalling the legal arguments set out in paragraphs 13 to 18 above, considers it necessary that action should be taken to succour and assist those who, in Afghanistan, are suffering the most harshly from the lack of goods essential to life and survival. This action to help the populations in distress should be immediate. It should be accompanied by medium-term action to give the populations the possibility of continuing to live on their own land.

\section{URGENT AND MEDIUM-TERM ASSISTANCE}

73. The Commission considers, on the basis of studies in this field, that urgent action must be undertaken in three regions particularly threatened by hunger : the Panjshir, Badakhshan and the western Hazaradjat. Their vulnerability is due to military offensives which have driven great numbers of people to areas at a great altitude where survival is difficult, to the destruction of vital commercial communications between traditional surplus and deficit areas; to the par city of snowfall in the winter of $1983 / 84$, and to the failure of the spring rains which have resulted in an extremely poor harvest.

74. It is important that humanitarian aid should meet a certain number of development criteria such as :

- support and reinforcement of local distribution and of trading networks between surplus and deficit areas;

- encouragement of agricultural production by guaranteeing

the sale of harvests ;

- support of local administrations which have made efforts 
to protect the living conditions of the non-combatant population; - avoidance of any dependency on free distribution of foodstuffs, by using the existing marketing system as the means of distribution.

75. Medium-term aid should be strengthened in unoccupied areas. For practical reasons, priority in this field should be given to regions most sheltered from the war.

By the means, three equally important purposes will be served: a) the process of economic readjustment and self-adjustment will be reinforced and the vulnerability of the traditional economy reduced ;

b) a contribution will be made to the improvement of the living conditions of displaced persons who seek refuge in the regions least affected by the war;

c) regions are strengthened which may in future serve as a refuge for civil populations. criteria :

It is desirable that medium-term aid should be based on certain

- maintenance of the means of production ;

- maintenance of networks of distribution and exchange ;

- reliance on and promotion of traditional skills;

- leaving it to local administrations to define their needs.

76. The Commission has received a number of suggestions about various fields in which aid to regional reconstruction might be considered.

a). economic ;

- preparation and restoration of cultivable land (irrigation, improvement of seed, etc) ;

- preparation of new fields in safe areas, for example in mountainous regions;

- nursery gardens for young trees;

- reconstruction of stock-raising, which has always been at the economic base of the life of most Afghan populations ;

- aid for craftmen.

b). medical :

in addition to curative medecine, development of training for medical and para-medical personnel.

c). education :

- reinforcement and extension of existing schools;

- training courses for adults in technical fields such as agriculture, stock-raising, building and other crafts.

77. The Commission considers however that this multi-purpose assistance, which should be set up gradually with great caution and with the agreement and under the authority of local leaders, can only be adapted to concrete needs and conditions on the spot when the process has actually started. 


\section{THE RIGHT TO PROTECTION}

78. The Commission asserts and demands the recognition of a double right :

- the right of all civilian populations to receive aid indispensable to life and survival:

- the right of persons who bring them this aid to protection in carrying out their mission.

Protection of medical missions is claimed in the draft Convention presented by the International Human Rights Federation to the strasbourg symposium on 28 and 29 January, 1984 (see annex 6).

The safety of journalists on dangerous professional missions is also of current concern. The ICRC has just arranged an international seminar on this subject at vevey on 23 and 24 April, 1985.

A fortiori, when persons are mandated to carry out humanitarian mission's in the dangerous conditions of a country at war, the Commission considers that their safety should be assured. Such protection cannot be a personal privilege granted to humanitarian personnel, but the corollary of standards designed to guarantee the respect and protection of any civilian population in danger. 


\title{
CONCLUSIONS AND RECOMRENDATIONS
}

\author{
In the course of its work, the Commission reached the following \\ conclusions :
}

1. The war which has lasted over five years has profoundly shaken the basic structure of Afghan society. Out of a population of 15 million in 1978, nearly half have been forcibly displaced, either without or within the country's national frontiers. In addition to the 3 million refugees registered in Pakistan and the 1,5 million reported in Iran, the Commission believes the number of those displaced within the country itself, or "internal refugees", to amount to about 2 million.

2. As the present report makes clear, the direct causes of internal displacement are combat, bombing, fear, poverty and starvation. When they abandon their homes, villages and lands, internal refugees lose their livelihood and find themselves in precarious circumstances: bereft of any sort of defence or protection, in contrast to those refugees sheltered abroad who enjoy the protection of host Governments and the assistance extended by the international community.

The Commission whishes to remind observers that displaced noncombatant populations are entitled to the protection afforded by universally recognized humanitarian principles as expressed by the Geneva Conventions of 1949 with the Additional Protocols of 1977, and that the parties to the conflict are bound by these principles.

3. As it happens, the displaced populations under consideration receive no assistance other than that extended by neighbouring host populations within the same national frontiers, affected by the same war and under additional strain to cope with the added economic burden. The Commission wishes to point out that several areas present a serious risk of famine. In those villages and valleys where internal refugees have sought safety, the absolute basics for life and survival are often to be found lacking : shelter, food, heating and medecine.

4. Parallel to necessary efforts deployed to hasten an end to the war, the Commission believes that immediate relief operations should be undertaken and long-term assistance extended on behalf of displaced persons in Afghanistan. At stake in the present case is the international community's duty to intervene in order to bring relief to persons whose most elementary rights are ignored or trod underfoot, and whose very physical existence stands in jeopardy.

5. The Commission recommends that Governments and Inter-Governmental Organizations, as certain European Governments have already done, furnish those Non-Governmental Organizations (NGO's), already involved in relief work on behalf of Afghan non-combatant populations, with the necessary means to cope with present needs. 
6. The Commission recommends that emergency relief operations be supplemented with longer-term operations aiming to help reconstruct devastated areas and give those populations still presently spared the means to continue living on their own lands.

7. The Commission notes that NGO's operating amongst Afghan noncombatant populations in those zones not under control of the present Kabul authorities, have had to assume the rôle of substitutes to those international organizations -such as the International Committee of the Red Cross- whose intervention on Afghan soil is refused or prevented. The Commission considers that persons mandated by NGO's for humanitarian missions under dangerous conditions in countries at war, are entitled to ensured forms of security and protection.

8. The Commission states -and requests- recognition of a dual right :

- the right by which any non-combatant population is entitled to assistance indispensable to its life and survival:

- the right by which those persons extending such assistance are entitled to protection in the course of their mission.

Geneva, April 26, 1985 
Fourth Geneva Convention, relative to the protection of civilian persons in time of war

Each High Contracting Party shall allow the free passage of all consignments of medical and hospital stores and objects necessary for religious worship intended only for civilians of another High Contracting Party, even if the latter is its adversary. It shall likewise permit the free passage of all consignments of essential foodstuffs, clothing and tonics intended for children under fifteen, expectant mothers and maternity cases.

The obligation of a High Contracting Party to allow the free passage of the consignments indicated in the preceding paragraph is subject to the condition that this Party is satisfied that there are no serious reasons for fearing :

(a) that the consignments may be diverted from their destination,

(b) that the control may not be effective, or

(c) that a definite advantage may accrue to the military efforts or economy of the enemy through the substitution of the above-mentioned consignments for goods which would otherwise be provided or produced by the enemy or through the release of such material, services or facilities as would otherwise be required for the production of such goods.

The Power which allows the passage of the consignments indicated in the first paragraph of this Article may make such permission conditional on the distribution to the persons benefited thereby being made under the local supervision of the Protecting Powers.

Such consignments shall be forwarded as rapidly as possible, and the Power which permits their free passage shall have the right to prescribe the technical arrangements under which such passage is allowed.
Consignment of medical supplies, food a is clothing.

\section{Protocol I additional to the Geneva Convention}

\section{- Relief actions}

1. If the civilian population of any territory under the control of a Party to the conflict, other than occupied territory, is not adequately provided with the supplies mentioned in Article 69, relief actions which are humanitarian and impartial in character and conducted without any adverse distinction shall be undertaken, subject to the agreement of the Parties concerned in such relief actions. Offers of such relief shall not be regarded as interference in the armed confiict or as unfriendly acts. In the distribution of relief consignments, priority shall be given to those persons, such as children, expectant mothers, maternity cases and nursing mothers, who, under the Fourth Convention or under this Protocol, are to be accorded privileged treatment or special protection.

2. The Parties to the conflict and each High Contracting Party shall allow and facilitate rapid and unimpeded passage of all relief consignments, equipment and personnel provided in accordance with this Section, even if such assistance is destined for the civilian population of the adverse Party. 
3. The Parties to the conflict and each High Contracting Party which allow the passage of relief consignments, equipment and personnel in accordance with paragraph 2 :

(a) shall have the right to prescribe the technical arrangements, including search, under which such passage is permitted;

(b) may make such permission conditional on the distribution of this assistance being made under the local supervision of a Protecting Power;

(c) shall, in no way whatsoever, divert relief consignments from the purpose for which they are intended nor delay their forwarding, except in cases of urgent necessity in the interest of the civilian population concerned.

4. The Parties to the conflict shall protect relief consignments and facilitate their rapid distribution.

5. The Parties to the conflict and each High Contracting Party concerned shall encourage and facilitate effective international co-ordination of the relief actions referred to in paragraph 1.

1. Where necessary, relief personnel may form part of the assistance provided in any relief action, in particular for the transportation and distribution of relief consignments; the participation of such personnel shall be subject to the approval of the Party in whose territory they will carry out their duties.

2. Such personnel shall be respected and protected.

3. Each Party in receipt of relief consignments shall, to the fullest extent practicable, assist the relief personnel referred to in paragraph 1 in carrying out their relief mission. Only in case of imperative military necessity may the activities of the relief personnel be limited or their movements temporarily restricted.

4. Under no circumstances may relief personnel exceed the terms of their mission under this Protocol. In particular they shall take account of the security requirements of the Party in whose territory they are carrying out their duties. The mission of any of the personnel who do not respect these conditions may be terminated. 
Protocol II additional to the Geneva Conventions

Article 14

- Protection of objects indispensable to the survival of the civilian population

Starvation of civilians as a method of combat is prohibited. It is therefore prohibited to attack, destroy, remove or render useless, for that purpose, objects indispensable to the survival of the civilian population, such as foodstuffs, agricultural areas for the production of foodstuffs, crops, livestock, drinking water installations and supplies and irrigation works.

Article 18 - Relief socieries and relief actions

1. Relief societies located in the territory of the High Contracting Party, such as Red Cross (Red Crescent, Red Lion and Sun) organizations, may offer their services for the performance of their traditional functions in relation to the victims of the armed conflict. The civilian population may, even on its own initiative, offer to collect and care for the wounded, sick and shipwrecked.

2. If the civilian population is suffering undue hardship owing to a lack of the supplies essential for its survival, such as foodstuffs and medical supplies, relief actions for the civilian population which are of an exclusively humanitarian and impartial nature and which are conducted without any adverse distinction shall be undertaken subject to the consent of the High Contracting Party concerned. 


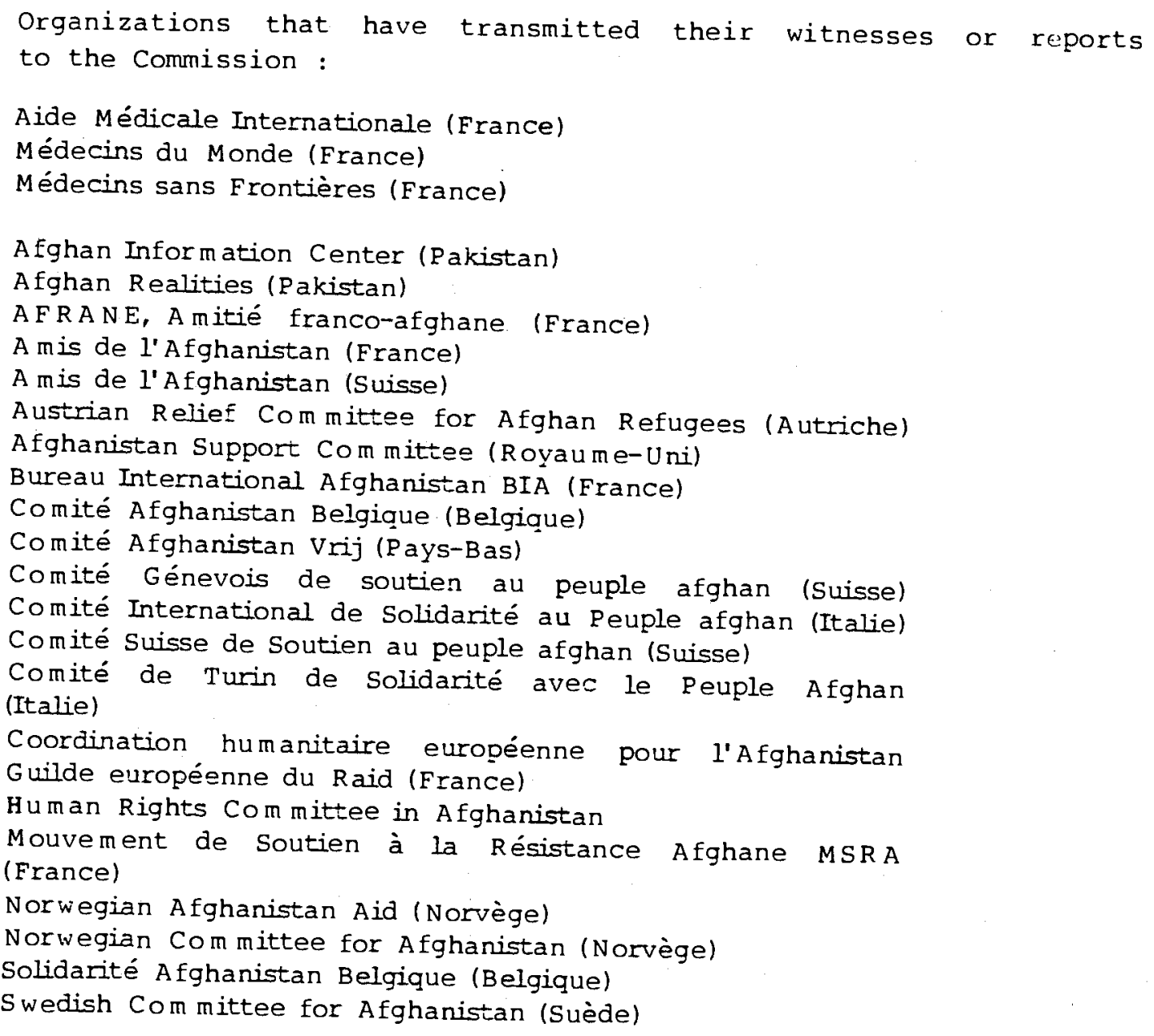


Annex 5

Other sources:

Permanent Peoples' Tribunal sentences on Afghanistan, Un Tribunal pour les peuples, Collection Monde en Devenir directed by Edmond Jouve, Edition Berger-Levrault, Paris, 1983

International Afghanistan Hearing, Final Report, Oslo, 1983

Francès D'Souza, The Threat of Famine in Afghanistan, London, 1984

Helsinki watch, Tears, Blood and Cries, Human Rights in Afghanistan since the Invasion 1979-1984, New-York, 1984

Alerte à la famine en Afghanistar, Press book prepared by Amitié francoafghane (AFRANE), Aide médicale internationale (AMI), Guilde européenne du raid, Médecins du monde (MdM), Médecins sans frontières (MsF), Paris, 12 décembre 1984. Report on the Human Rights situation in Afghanistan, drawn up by Mr
Felix Ermacora, Special Rapporteur, United Nations Economical and
Social Council. Human Rights Social Council, Human Rights Commission, 41 st Session, 1985 


\section{Charter for the Protection of Medical Missions}

Several humanitarian medical associations assigned to themselves the mission of coming to the aid of civil populations deprived of medical care. They consider that one of the fundamental rights of man, wherever and whoever he may be, is to be able to receive medical care and that this right has no territorial borders.

These associations have thus engaged themselves since a number of years of voluntary medical missions everywhere where their presence was required or necessary. But they have run into very serious difficulties (captures, detentions, incarcerations, acts of violence against their members, bombardments of their medical care centers, etc.) which have cruelly put into light the absence of any organized international protection of the medical personnel belonging to these non-governmental medical associations.

If, in fact, the additional protocoles (1977) of the Geneva Convention (August 12, 1949) and particularly the protocole II, put into effect a protection of the medical personnel intervening in non-international armed conflicts, it must be underlined that :

- for one, that the personnel which is protected by the terms of this agreement is : either working under the responsability of the ICRC or has been sent by a specific State, both of which exclude any medical personne! belonging to a non-governmental organization.

- secondly, that these protocoles have to this day been ratified only by 25 States, which, pratically speaking, renders their application illusionary.

It appears urgent and necessary in this context to aóoirm and demand the recognition of a double right :

- the right of every civilian population to be treated by a medical personne! which offers guarantees of competence and impartiality.

This guarantee could be endowed by the recognition of the voiuniary humanitarian organizations of which the personnel are members, or by the International Federation of Humanitarian Organizations, medical and voluntary, which is in the course of being formed.

- the right to protection of the medical personnel in the accomplishment of their medical mission. This protection should not be the single privilege of the medical personnel but the consequence of a set norms aimed at guaranteing the respect and the protection of every population in danger. 
This right, the clauses of which are detailed below, should be accompanied by obligations assigned to the medical personnel which should present themselves as follows:

1

The medical personnel who offer their services to civilian population must respect the laws of medical deontology.

2

The medical care should be distributed for none other than medical criteria.

3

The will of the people treated must be respected.

4

The medical personnel on mission must be able to be identified. It can use a professional card delivered by the CICR or by the International Federation of Humanitarian Organizations where the humanitarian organization for which it works was accredited.

The rights of the medical personnel in mission are the following:

1

The medical personnel must be protected and respected. They can not be punished or troubled for having excercised a medical activity regardless of who the beneficiary may be.

2

The medical personnel must be able to reach the place where their care is indispensable.

They cannot be forced to give out information concerning persons to whom they have given medical' care.

4

If a member of a medical crew is, because of his medical activities, arrested by any authorities of the territory in which he is filling out his mission or by an opposing party to this one, he must be set free and repatriated without delay.

Charter presented by the Intemational Federation on Human Rights at the Colloquium in Strasbourg February 28 and 29, 1984. 


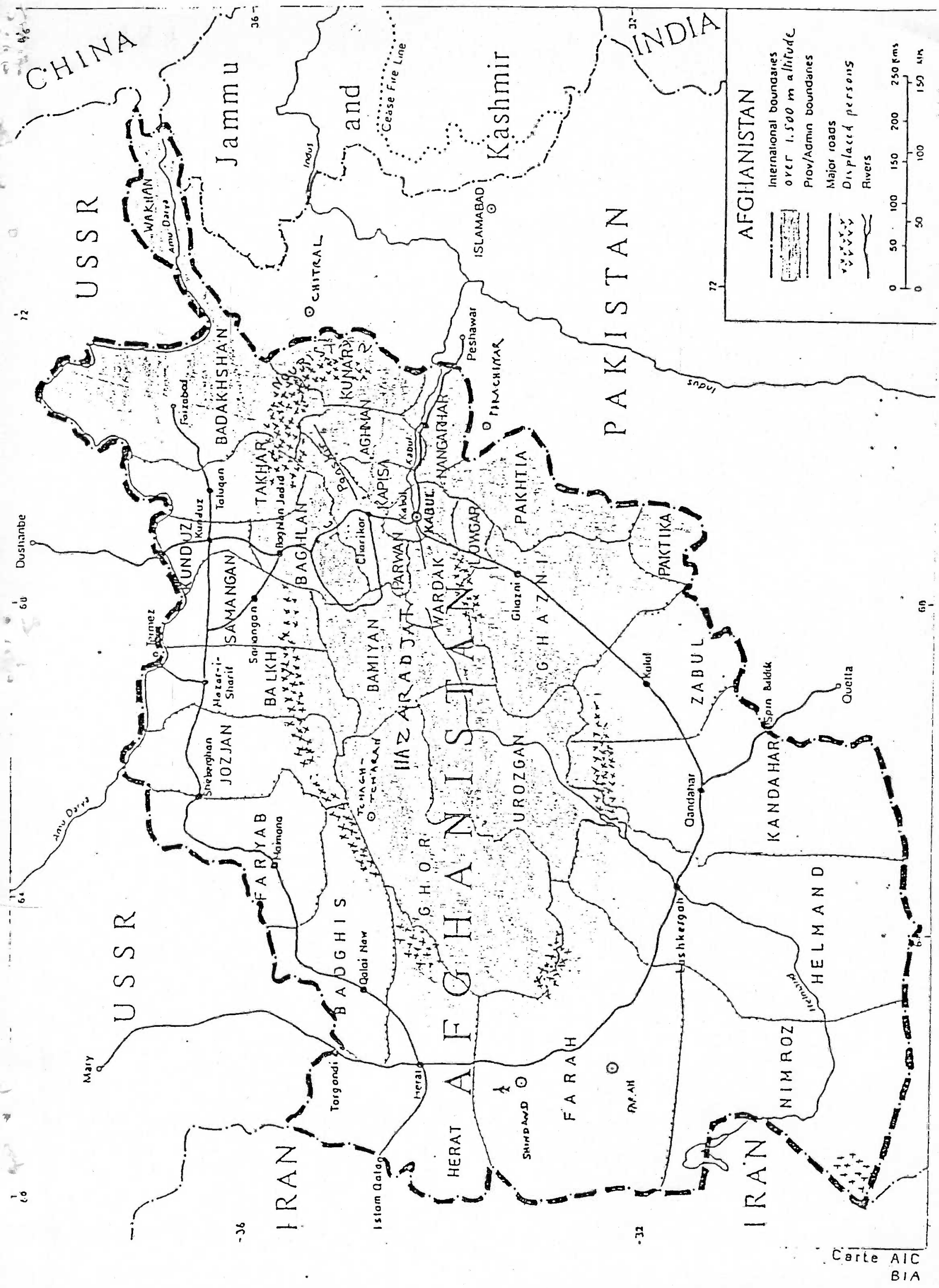

